\title{
The impact of maternal obesity on maternal and fetal outcome
}

\author{
Esther Kamalarani A. ${ }^{1}$, Ramyajothi ${ }^{2 *}$, Ramalakshmi S. ${ }^{1}$ \\ ${ }^{1}$ Department of Obstetrics and Gynecology, Tirunelveli Medical College Hospital, Tamil Nadu, India \\ ${ }^{2}$ Department of Obstetrics and Gynecology, Dr. Rela Institute of Medical Sciences, Chennai, Tamil Nadu, India
}

Received: 09 June 2019

Revised: 27 November 2019

Accepted: 02 December 2019

\author{
*Correspondence: \\ Dr. Ramyajothi, \\ E-mail: estherkamalarani@gmail.com
}

Copyright: () the author(s), publisher and licensee Medip Academy. This is an open-access article distributed under the terms of the Creative Commons Attribution Non-Commercial License, which permits unrestricted non-commercial use, distribution, and reproduction in any medium, provided the original work is properly cited.

\section{ABSTRACT}

Background: Obesity continues to be a global health concern. Although the increasing obesity rates in developed countries has slowed down in the past 10 years, obesity rates in developing countries continue to increase, as much as three times in some developing countries over the past 30 years. The aim of the study was to determine the adverse effects of obesity in pregnancy and maternal and fetal outcome.

Methods: In all patients, a detailed history was taken and examinations and investigations were carried out. Based on BMI (body mass index), patients were divided into 2 groups. Group $1=$ patients with BMI $>30 \mathrm{~kg} / \mathrm{m}^{2}$ and Group $2=$ patients with BMI $<30 \mathrm{~kg} / \mathrm{m}^{2}$.

Results: In our study, comparing pregnant mothers with BMI $>30 \mathrm{~kg} / \mathrm{m}^{2}$ and normal BMI, authors found that the prevalence of maternal and fetal complications was higher in the obese group. Prevalence of antenatal complications like gestational hypertension, preeclampsia, imminent eclampsia and gestational diabetes mellitus requiring control with insulin was higher in obese women.

Conclusions: Obesity is associated with increased adverse effects on pregnancy and its outcome.

Keywords: Complications, Maternity complication, Maternal outcome, Obesity, Overweight, Pregnancy

\section{INTRODUCTION}

Over the past two decades the prevalence of obesity has increased so much both in developing and developed countries. It is associated negatively with the level of physical activity. Obesity is viewed as sixth important public health problem which causes several diseases like chronic hypertension, diabetes, cardiovascular diseases, stroke, cancer etc. This will cause decreased life expectancy in the future. ${ }^{1}$ WHO declares obesity as a pandemic issue, having high prevalence in females, especially in the childbearing age than in males. ${ }^{2}$ Pregnancies complicated by obesity has been identified as early as $1945 .^{3}$ Pre-pregnancy obesity endangers both maternal and fetal well-being. Increasing BMI is associated with increased adverse obstetric and fetal outcomes, especially higher incidence of pre-eclampsia, gestational diabetes, abnormal labour, cesarean section, fetal macrosomia, unexplained fetal death, respiratory distress and neonatal death.

The aim of the study is to determine the adverse effects of obesity in pregnancy on maternal and fetal outcome.

\section{METHODS}

This prospective observational study was conducted in the department of obstetrics and gynaecology, Tirunelveli Medical College Hospital from 2016 to 2017. Based on BMI, patients were divided into 2 groups. Group $1=$ patients with BMI $>30 \mathrm{~kg} / \mathrm{m}^{2}$ and Group $2=$ patients with $\mathrm{BMI}<30 \mathrm{~kg} / \mathrm{m}^{2}$. About 100 patients who visited 
TVMCH during the first trimester were enrolled in the study after obtaining proper informed consent. In all the patients a detailed history was taken, examinations and investigations were carried out. Their BMI was calculated by the Quetelet index and each of them was allotted into 2 groups based on their BMI. Patients were advised to have at least 3 antenatal visits in TVMCH, and suggested to have delivery in TVMCH for a proper follow-up.

\section{Inclusion criteria}

- Primigravida

- $\quad$ Singleton pregnancies

- Age $>18$ years $<40$ years

- Patients booking in TVMCH in the first trimester.

\section{Exclusion criteria}

- Multigravida

- Age $<18$ years $>40$ years

- Patients booking in TVMCH beyond the first trimester

- Multiple gestation

- Chronic hypertension and pre-existing renal disease

- Diabetes mellitus

- Previous history of thromboembolic disease

- Previous history of connective tissue disorder.

\section{Statistical analysis}

Data were collected and continuable variables analyzed using student $\mathrm{t}$ test, categorical variables analyzed using chi square test and SPSS version 16.

\section{RESULTS}

In this study, authors found that the mean age for women in the category BMI $<30 \mathrm{~kg} / \mathrm{m}^{2}$ was 23.38 years and in BMI $>30 \mathrm{~kg} / \mathrm{m}^{2}$ it was found to be 26.18 years. In this study only $16 \%$ of the non-obese and $8 \%$ obese were found to be anemic. This study showed that $22 \%$ of obese women were hypothyroid compared to $14 \%$ of nonobese women which was statistically insignificant. $51 \%$ of the obese women developed gestational hypertension (GHTN) when compared to only $14.3 \%$ of the nonobese women which was statistically significant with a p-value of $<0.001$. Similarly, development of preeclampsia was higher in obese women. About $36.7 \%$ of obese women developed preeclampsia compared to $4.1 \%$ nonobese women which were also statistically significant with a pvalue of $<0.001$. Also, the incidence of imminent eclampsia was high in obese women $(22.4 \%)$ while only $2 \%$ of nonobese group developed imminent eclampsia. This was also statistically significant with p-value 0.002 . The development of eclampsia and abruption was relatively lower in both the groups and was statistically insignificant. About $10.2 \%$ of the obese women and none of the controls developed GDM requiring insulin for control. This was statistically significant with a p-value of 0.022 (Table 1).

Table 1: Comparison of an risk factors characteristics with BMI.

\begin{tabular}{|c|c|c|c|c|}
\hline \multirow{2}{*}{ Variables } & & \multicolumn{2}{|l|}{ BMI } & \multirow{2}{*}{$\begin{array}{l}\text { p- } \\
\text { value }\end{array}$} \\
\hline & & $<=30$ & $>\mathbf{3 0}$ & \\
\hline \multirow{2}{*}{ Preterm } & No & 40 & 42 & \multirow{2}{*}{0.585} \\
\hline & Yes & 9 & 7 & \\
\hline \multirow{2}{*}{ Post term } & No & 46 & 45 & \multirow{2}{*}{0.183} \\
\hline & Yes & 1 & 4 & \\
\hline \multirow{2}{*}{$\begin{array}{l}\text { GDM medi } \\
\text { nutritional } \\
\text { therapy }\end{array}$} & No & 46 & 40 & \multirow[b]{2}{*}{0.064} \\
\hline & Yes & 3 & 9 & \\
\hline \multirow{2}{*}{$\begin{array}{l}\text { GDM } \\
\text { OHA }\end{array}$} & No & 49 & 48 & \multirow{2}{*}{0.315} \\
\hline & Yes & 0 & 1 & \\
\hline \multirow{2}{*}{$\begin{array}{l}\text { GDM } \\
\text { insulin }\end{array}$} & No & 49 & 44 & \multirow{2}{*}{0.022} \\
\hline & Yes & 0 & 5 & \\
\hline \multirow{6}{*}{ Others } & AKI & 0 & 1 & \multirow{6}{*}{0.441} \\
\hline & Heart diseases & 1 & 3 & \\
\hline & Low lying placenta & 0 & 1 & \\
\hline & Oligohydramnios & 6 & 7 & \\
\hline & Polyhydramnios & 0 & 2 & \\
\hline & Rupture membrane & 1 & 0 & \\
\hline
\end{tabular}

Table 2: Comparison of induction of labor with BMI.

\begin{tabular}{|c|c|c|c|c|}
\hline \multirow{2}{*}{ Variables } & & \multicolumn{2}{|l|}{ BMI } & \multirow{2}{*}{ P-value } \\
\hline & & $<=30$ & $>\mathbf{3 0}$ & \\
\hline \multirow{2}{*}{ Induction } & No & 37 & 28 & \multirow{2}{*}{0.037} \\
\hline & Yes & 11 & 21 & \\
\hline \multirow{2}{*}{ Failed induction } & No & 30 & 14 & \multirow{2}{*}{0.001} \\
\hline & Yes & 19 & 35 & \\
\hline \multirow{2}{*}{$\mathrm{LN}$} & No & 22 & 36 & \multirow{2}{*}{0.004} \\
\hline & Yes & 27 & 13 & \\
\hline \multirow{2}{*}{ Forceps } & No & 46 & 45 & \multirow{2}{*}{0.695} \\
\hline & Yes & 3 & 4 & \\
\hline \multirow{2}{*}{ Vacuum } & No & 45 & 47 & \multirow{2}{*}{0.629} \\
\hline & Yes & 3 & 2 & \\
\hline \multirow{2}{*}{ Difficult delivery } & No & 44 & 47 & \multirow{2}{*}{0.385} \\
\hline & Yes & 4 & 2 & \\
\hline
\end{tabular}

In this study, about $42.9 \%$ of obese women required induction of labour when compared to only $22.9 \%$ in the normal BMI group with a statistically significant ' $p$ ' value of 0.037 . The incidence of failed induction was also higher $-71.4 \%$ in $\mathrm{BMI}>30 \mathrm{~kg} / \mathrm{m}^{2}$ category and $38.8 \%$ in the BMI $<30 \mathrm{~kg} / \mathrm{m}^{2}$ category, which was statistically significant with a ' $p$ ' value of 0.001 . This study showed that many women with normal BMI delivered vaginally compared to obese women $(55.1 \%$ versus $26.5 \%)$. This was statistically significant with 'p' value of 0.004 . There was no significant difference in operative vaginal deliveries in both groups. In the group with BMI $>30$ $\mathrm{kg} / \mathrm{m}^{2}, 8.2 \%$ of women delivered by forceps and $4.1 \%$ delivered by vacuum, whereas in the group with BMI < 
$30 \mathrm{~kg} / \mathrm{m}^{2}, 6.1 \%$ of women delivered by forceps and $6.2 \%$ delivered by vacuum (Table 2). In this study, difficulty in delivering the baby vaginally, deep transverse arrest and shoulder dystocia could not be observed much in both the groups (Table 3).

Table 3: Intra OP complications with BMI.

\begin{tabular}{|c|c|c|c|c|}
\hline \multirow{2}{*}{\multicolumn{2}{|c|}{ Variables }} & \multicolumn{2}{|l|}{ BMI } & \multirow{2}{*}{ P-value } \\
\hline & & $<=30$ & $>\mathbf{3 0}$ & \\
\hline \multirow{2}{*}{ Shoulder dystocia } & No & 46 & 49 & \multirow{2}{*}{0.149} \\
\hline & Yes & 2 & 0 & \\
\hline $\begin{array}{l}\text { Deep transverse } \\
\text { arrest }\end{array}$ & No & 48 & 49 & - \\
\hline \multirow{2}{*}{ MSAF } & No & 43 & 46 & \multirow{2}{*}{0.653} \\
\hline & Yes & 4 & 3 & \\
\hline \multirow{2}{*}{ Delay in progress } & No & 43 & 36 & \multirow{2}{*}{0.021} \\
\hline & Yes & 4 & 13 & \\
\hline \multirow{2}{*}{$\begin{array}{l}\text { Failure of } \\
\text { secondary powers }\end{array}$} & No & 44 & 42 & \multirow{2}{*}{0.355} \\
\hline & Yes & 4 & 7 & \\
\hline \multirow{2}{*}{ PPH } & No & 46 & 47 & \multirow{2}{*}{0.983} \\
\hline & Yes & 3 & 2 & \\
\hline \multirow{2}{*}{ Elective LSCS } & No & 48 & 47 & \multirow{2}{*}{0.646} \\
\hline & Yes & 1 & 2 & \\
\hline \multirow{2}{*}{ Malpresentation } & No & 43 & 45 & \multirow{2}{*}{0.168} \\
\hline & Yes & 6 & 4 & \\
\hline \multirow{2}{*}{ CPD } & No & 36 & 36 & \multirow{2}{*}{0.074} \\
\hline & Yes & 13 & 13 & \\
\hline \multirow{2}{*}{ Emergency LSCS } & No & 47 & 21 & \multirow{2}{*}{0.002} \\
\hline & Yes & 2 & 28 & \\
\hline \multirow{2}{*}{ Diff. delivery } & No & 49 & 46 & \multirow{2}{*}{0.646} \\
\hline & Yes & 0 & 3 & \\
\hline \multirow{2}{*}{ Hysterectomy } & No & 49 & 48 & \multirow{2}{*}{0.315} \\
\hline & Yes & 0 & 1 & \\
\hline
\end{tabular}

Table 4: Post OP complications with BMI.

\begin{tabular}{|c|c|c|c|c|}
\hline \multirow{2}{*}{ Variables } & & \multicolumn{2}{|l|}{ BMI } & \multirow{2}{*}{$\begin{array}{l}\text { P- } \\
\text { value }\end{array}$} \\
\hline & & $<=30$ & $>\mathbf{3 0}$ & \\
\hline \multirow{3}{*}{$\begin{array}{l}\text { Post OP } \\
\text { complications }\end{array}$} & Diarrhoea & 0 & 1 & \multirow{3}{*}{0.632} \\
\hline & Fever & 2 & 3 & \\
\hline & Wound infection & 1 & 4 & \\
\hline \multirow{2}{*}{ Baby } & Alive & 46 & 43 & \multirow{2}{*}{0.294} \\
\hline & Intrauterine death & 3 & 6 & \\
\hline
\end{tabular}

Meconium staining of the amniotic fluid during labour was observed to be more or less similar in both the groups which were also not comparable. But delay in the progress of labour was noticed in about $26.5 \%$ of the obese mothers and in only $8.5 \%$ of the nonobese mothers. This was statistically significant with ' $p$ ' value of 0.021 . The incidence of intrapartum fetal demise was higher in obese women about $12.2 \%$ but only $6.1 \%$ in the nonobese group. This can be due to increased association of obesity with GDM, preeclampsia and IUGR which can cause sudden intrauterine fetal death (Table 4).
Table 5: Perinatal outcome comparison with BMI.

\begin{tabular}{|c|c|c|c|c|}
\hline \multirow{2}{*}{ Variables } & & \multicolumn{2}{|l|}{ BMI } & \multirow{2}{*}{$\begin{array}{l}\text { P- } \\
\text { value }\end{array}$} \\
\hline & & $<=30$ & $>\mathbf{3 0}$ & \\
\hline \multirow{3}{*}{ Gestational age } & IUGR & 1 & 6 & \multirow{3}{*}{0.146} \\
\hline & Preterm & 9 & 8 & \\
\hline & Term & 39 & 35 & \\
\hline \multirow{2}{*}{ Birth asphyxia } & No & 41 & 38 & \multirow{2}{*}{0.91} \\
\hline & Yes & 5 & 5 & \\
\hline \multirow{2}{*}{ Distress } & No & 30 & 25 & \multirow{2}{*}{0.492} \\
\hline & Yes & 16 & 18 & \\
\hline NEC & No & 46 & 43 & - \\
\hline \multirow{2}{*}{ HMD } & No & 46 & 40 & \multirow{2}{*}{0.068} \\
\hline & Yes & 0 & 3 & \\
\hline \multirow{2}{*}{ Anomalies } & No & 46 & 42 & \multirow{2}{*}{0.298} \\
\hline & Yes & 0 & 1 & \\
\hline \multirow{2}{*}{ Seizure } & No & 43 & 35 & \multirow{2}{*}{0.083} \\
\hline & Yes & 3 & 8 & \\
\hline \multirow{2}{*}{ Hypoglycemia } & No & 43 & 38 & \multirow{2}{*}{0.04} \\
\hline & Yes & 3 & 5 & \\
\hline \multirow{2}{*}{ Hypothermia } & No & 44 & 37 & \multirow{2}{*}{0.113} \\
\hline & Yes & 2 & 6 & \\
\hline \multirow{2}{*}{ Jaundice } & No & 37 & 32 & \multirow{2}{*}{0.497} \\
\hline & Yes & 9 & 11 & \\
\hline \multirow{2}{*}{ Phototherapy } & No & 37 & 32 & \multirow{2}{*}{0.497} \\
\hline & Yes & 9 & 11 & \\
\hline
\end{tabular}

About $57.1 \%$ of patients in the obese group and $26.5 \%$ of the normal women required an emergency cesarean section. The main reason for this could be because of the higher rates of failed induction, undue delay in the progress of the process of labour and failure of uterine contraction and maternal efforts. From our study, it is shown that the risk of atonicity and hemorrhage was higher during the cesarean section in the obese women $(22.4 \%)$ that is 11 out of 50 members had increased blood loss during and after surgery. For one patient, atonicity could not be managed medically and by conservative procedures and so has to proceed with peripartum hysterectomy. This was not observed in normal BMI women. Authors found that the incidence of malpresentation was $8.25 \%$ in the obese women and $2 \%$ in nonobese women. This was statistically insignificant with a ' $p$ ' value of 0.168 . Also, the incidence of cephalopelvic disproportion was higher in the obese group which was $26.5 \%$ compared to the normal BMI women which was only $12.2 \%$. This was due to fetal macrosomia and increased fetal weight in obese individuals. Results of this study showed that the mean birth weight of babies in the obese individuals was 2.63 $\mathrm{kg}$ and in the non-obese individuals was $2.57 \mathrm{~kg}$. Like in other studies, fetal macrosomia and increased mean birth weight were not observed in this study. This can be due to of increased incidence of associated preeclampsia and IUGR and iatrogenic premature termination of pregnancies due to other complications. This results showed that the incidence of post-term pregnancy (ie) gestational age > 41 weeks was higher in the obese 
individuals, which was $8.2 \%$ in the obese and only $2.1 \%$ in the nonobese group which was not statistically significant with ' $p$ ' value 0.183 . Only 4 out of 50 in the obese group and 1 out of 50 in the non-obese group carried gestation beyond 41 weeks. This is because of the close follow-up of the cases in the study and only 5 patients lost follow-up during the last few weeks of gestation. The rate of preterm delivery (ie) gestational age $<37$ weeks was slightly higher in the nonobese group with incidence being $18.4 \%$ and $14.3 \%$ in the obese individuals. This was also statistically insignificant with a ' $p$ ' value of 0.585 . The incidence of anomalous babies in obese mothers was $2.3 \%$ while no cases were observed in the nonobese group. The incidence of intrauterine death was $12.2 \%$ in the obese group which was double the rate in the normal BMI group. This is due to associated risks like gestational hypertension and gestational diabetes mellitus in obese mothers (Table 5).

\section{DISCUSSION}

Lashen et al, did a nested control study on obesity and risk of first trimester and recurrent miscarriages in 2004 from a database of Solihull maternity unit. ${ }^{4}$ They compared 1644 obese women with 3288 normal BMI women and concluded that the odds ratio of risk of early abortions and recurrent miscarriages in obese women were 1.2 and 3.5 which was statistically significant. But this was not proved in this study as the ' $p$ ' value of early trimester losses was statistically insignificant 0.427 . Elmar et al, proved in their study that obesity is a potential risk factor for nutritional deficiency anemia. But this results were similar to Gautier-Dereure $\mathrm{F}$ et al, studies who proved that anemia is less common in the obese women compared to nonobese controls., Senterkiwicz L et al, study states that TSH levels are higher with increasing BMI in pregnant women and also increases to about two to four-fold in the second trimester. $^{7}$ Voigt et al, study found that the risk of development of preeclampsia is statistically significant in obese women. ${ }^{8}$ Ehrenthel DB et al, study also confirmed that preeclampsia was more common in obese women with the p-value of $0.001 .^{9}$ Endeshaw $\mathrm{M}$ et al, studies showed that obesity in younger age is a risk factor for preeclampsia. ${ }^{10}$ They compared the data of 151 obese women and 302 nonobese women attending ANC at Ethiopia and found that the adjusted odds ratio (AOR) was 3.33 in the obese women than their normal BMI counterparts. Sushan Y et al, did a meta-analysis from relevant articles regarding obesity and risk of GDM and found that the odds ratio for this in overweight, obese, severely obese were $2.14,3.56$ and 8.56 respectively indicating the risk of developing GDM was higher in higher BMI. ${ }^{11}$ This study also showed similar results. However, Kongubol A, studies showed that higher body weight in pre-pregnant period without any metabolic complications did not increase the risk of GDM in obese women during pregnancy. ${ }^{12}$ Wolfe $\mathrm{KB}$ et al, found that the rate of induction increases with increasing BMI which was $28 \%$ in the nonobese and $34 \%$ in the obese category women. ${ }^{13}$ Similarly failure of induction of labour was also higher - $29 \%$ in the obese women and $13 \%$ in the normal women. Vahratian et al, found that the prime reason for more number of obese women requiring cesarean section for delivery was due to non-progress and delayed cervical dilatation. ${ }^{14}$ They concluded that normal BMI women took an average of 5.43 hours to proceed from $4 \mathrm{~cm}$ to full cervical dilatation while obese women with $\mathrm{BMI}>30 \mathrm{~kg} / \mathrm{m}^{2}$ took an average of 6.98 hours to show the same progress in cervical dilatation. This could be a reason why vaginal deliveries are more successful in normal women compared to obese women. Janga et al study showed that operative vaginal deliveries were less in the obese women which was only $3.4 \% .{ }^{15}$ This study also showed no significant difference in the rate of operative vaginal delivery in both groups. Dimuthuvinayagam et al, did a retrospective case-control study on the adverse impact of maternal obesity on intrapartum outcome. ${ }^{16}$ They compared 100 obese women and 100 nonobese women and they found that the odds ratio for the delay in the progress of labour, emergency cesarean sections and lower APGAR scores for the baby delivered was higher in the obese group compared to their normal counterparts. In this study also the delay in progress of labour was seen in about $26.5 \%$ of obese mothers and only $8.5 \%$ of non-obese mothers, which was statistically significant. Similarly, Bianco et al, study also found that the incidence of non-progress of labour was higher in the obese $(12.9 \%)$ than the nonobese $(7.3 \%)$ mothers. ${ }^{17}$ Bhatacharya et al, study on obesity showed that emergency cesarean section rates were $58.8 \%$ in the increased BMI women while it was only $41.5 \%$ in the normal BMI group which was significantly high. ${ }^{18}$ The results were similar to Pevzner L et al, who showed that the incidence of emergency cesarean sections rose from $21.3 \%$ in the normal BMI group to $29.8 \%$ in the obese group and $36.5 \%$ in the morbidly obese group. ${ }^{19}$ Our study also showed significantly increased emergency caesarean section rate in obese women $(57.1 \%$ versus $26.5 \%$ ). Perlow et al, study on obesity and cesarean sections proved that cesarean sections in the morbidly obese women were associated with higher morbidity. ${ }^{20}$ The mean blood loss of more than $1000 \mathrm{ml}$ was found to be $34.9 \%$ in the obese women\& only $9.3 \%$ in the nonobese women which was much higher. Bell $\mathrm{J}$ et al, study on obese women and perioperative complications in cesarean delivery found that there is an increase in the total duration of the surgery which further increased perioperative morbidity. ${ }^{21}$ Dinatale et al, study found that the rates of incision site wound infection are more common in obese women because of the overhanging fold of subcutaneous tissue. ${ }^{22}$ Another major complication observed in that study was thrombophlebitis. They suggested prophylactic anticoagulation in such cases. In our study, no case of thrombophlebitis was reported because of use of prophylactic heparin in obese women. But incidence of wound infection was higher in obese category $(50 \%$ versus $33.3 \%$ ). Satpathy $\mathrm{HK}$ et al, study showed that the cesarean sections in obese mothers were commonly 
complicated by incision site infection and disruption. ${ }^{23}$ This is because, the area underlying the pannus is exposed to the moist and anaerobic environment. They also found a higher incidence of thrombophlebitis in obese individuals in the postoperative period. Denison et al, retrospective study on 186087 primigravidas from 1998-2002 showed about $6.8 \%$ of the obese primi delivered post-dated. ${ }^{24}$ The study concluded that higher maternal BMI and greater weight gain during pregnancy was associated with an increased risk of post-dated pregnancy. This study also showed similar result but it was statistically not significant.

\section{CONCLUSION}

Maternal obesity is now considered as one of the most commonly occurring risk factors in obstetric practice. Even with adequate prenatal care, obesity is associated with increased adverse effects in pregnancy and its outcome. Maternal obesity is strongly associated with antenatal complications like gestational diabetes mellitus, gestational hypertension and preeclampsia. Increase in need for induction of labour and increased operative deliveries is associated with maternal obesity. Maternal obesity is also associated with the increased amniotic fluid index, macrosomia and postpartum complications like wound infection and postpartum fever.

Funding: No funding sources

Conflict of interest: None declared

Ethical approval: The study was approved by the Institutional Ethics Committee

\section{REFERENCES}

1. James WP. WHO recognition of the global obesity epidemic. Int J Obes (Lond). 2008;32(Suppl7):S1206.

2. Satpathy HK, Fleming A, Frey D, Barsoom M, Satpathy C, Khandalavala J. Maternal obesity and pregnancy. Postgrad Med. 2008;120:E01-09.

3. Bhattacharya S, Campbell DM. Liston WA. Effect of body mass index on pregnancy outcome in nulliparous women delivering singleton babies. BMC Public Health. 2007; 7:168.

4. Lashen H, Fear K, Sturdee DW. Obesity is associated with increased risk of first trimester and recurrent abortions: matched case control study. Human Reproduct. 2004;19(7):1644-6.

5. Aigner E, Feldman A, Datsz S. Study on obesity as emerging risk factor for iron deficiency nutritional anemia. Nutrie. 2014;6(9):3587-600.

6. Galtier-Dereure F, Boegner C, Bringer J. Obesity and pregnancy: complications and cost. Am J Clin Nutr. 2000;71(5):1242S-1248s.

7. Senterkiewicz L, Krintus M, Junik R. Evaluation of risk of hypothyroidism in pregnant women with overweight and obesity. Endocr Abst. 2014;3:103545 .
8. Voigt M, Straube S, Zygmunt M, Krafczyk B, Schneider KT, Briese V. Obesity and pregnancy-a risk profile. Z Geburtshilfe Neonatol. 2008;212(6):201-5.

9. Ehrenthal DB, Jurkovitz C, Hoffman M, Jiang X, Weintraub WS. Prepregnancy body mass index as an independent risk factor for pregnancy-induced hypertension. J Womens Health (Larchmt). 2011;20(1):67-72.

10. Endeshaw M, Abebe F, Worku S, Menber L, Assress M, Assefa M. Obesity in young age is a risk factor for preeclampsia: a facility-based case-control study, northwest Ethiopia. BMC Preg Childbirth. 2016;16(1):237.

11. Chu SY, Callaghan WM, Kim SY, Schmid CH, Lau J, England LJ, et al. Maternal obesity and risk of gestational diabetes mellitus. Diabetes Care. 2007;30(8):2070-6.

12. Kongubol A, Phupong V. Prepregnancy obesity and the risk of gestational diabetes mellitus. BMC Preg Childbirth. 2011;11:59.

13. Wolfe KB, Rossi RA, Warshak CR. The effect of maternal obesity on the rate of failed induction of labor. Am J Obstet Gynecol. 2011;205(2):128.e1128.e7.

14. Vahratian A, Zhang J, Troendle JF. Maternal pre pregnancy weight and obesity and the pattern of labour progression in term nulliparous women. Obstet Gynecol. 2004;104:943-51.

15. Janga D, Parisaei M, Erskine K. Revisiting instrumental vaginal delivery rates in obese pregnant women. Arch Dis Childhood-Fetal Neonatal Edition. 2011;96(Suppl 1):Fa88.

16. Dimuthuvinayagam, Chandraharan E. The adverse impact of maternal obesity on intrapartum and perinatal outcomes. ISRN Obstet Gynecol. 2012; article ID 939762.

17. Bianco AT, Smilen SW, Davis Y, Lopez S, Lapinski R, Lockwood CJ. Pregnancy outcome and weight gain recommendations for the morbidly obese woman. Obstet Gynecol. 1998;91(1):97-102.

18. Bhattacharya S, Campbell DM, Liston WA, Bhattacharya S. Effect of body mass index on pregnancy outcomes in nulliparous women delivering singleton babies. BMC Public Health. 2007;7:168.

19. Pevzner L, Powers BL, Rayburn WF, Rumney P, Wing DA. Effects of maternal obesity on duration and outcomes of prostaglandin cervical ripening and labor induction. Obstet Gynecol. 2009;114(6):131521.

20. Perlow JH, Morgan MA. Massive maternal obesity and perioperative cesarean morbidity. Am J Obstet Gynecol. 1994;170:560-5.

21. Bell J, Bell S, VahratianA, Awonuga AO. Abdominal surgical incisions and perioperative morbidity among morbidly obese women undergoing cesarean delivery. Eu J Obstet Gynecol Repro Biol. 2011;154:16-9. 
22. Dinatale. Study on obesity and fetomaternal outcome. J Prenatal Med. 2010;4(1):5-8.

23. Satpathy HK, Fleming A, Frey D, Barsoom M, Satpathy C, Khandalavala J. Maternal obesity and pregnancy. Postgrad Med. 2008;120:E01-09.

24. Denison F, Price J, Graham C, Wild S, Liston W. Maternal obesity, length of gestation, risk of postdated pregnancy and spontaneous onset of labour at term. BJOG. 2008;115:720-5.

Cite this article as: Kamalarani EA, Ramyajothi, Ramalakshmi S. The impact of maternal obesity on maternal and fetal outcome. Int J Reprod Contracept Obstet Gynecol 2020;9:104-9. 